\title{
Biodegradation of toluene in a trickling filter
}

\author{
J. Peixoto, M. Mota
}

\begin{abstract}
A trickling filter packed with PVC $16 \mathrm{~mm}$ Raschig rings was used to study the degradation of toluene in a polluted air stream, by means of a bacterial biofilm of Pseudomonas putida ATCC 17484. A polluted stream was simulated by blending air with a controlled amount of toluene. The mixing was accomplished in a special mixing chamber designed for that purpose. Induction of the enzymes of the toluene degradative pathway and adaptation of the inoculum were done in batch cultures with minimum mineral media and phenol. The continuous experiments were monitored by mass spectrometry for the quantification of the various gases and of toluene removal. A 94\% toluene removal was achieved with contacting times above one minute and toluene concentrations up to $400 \mathrm{ppm}$.
\end{abstract}

\section{List of symbols \\ $T$ Temperature \\ $M \quad$ Molecular weight \\ $S \quad$ Solubility \\ $t_{C} \quad$ Contacting time \\ VOC Volatile organic compound \\ MS Mass spectrometer or mass spectrometry \\ $\rho \quad$ Density \\ EPA Environmental Protection Agency}

\section{1}

\section{Introduction}

An unlimited effort towards the creation of treatment technologies must oppose the certainty that progress cannot be achieved without the production of a great amount of inevitable pollutants, also minimizing their production by updating all the technologies and recycling processes.

Approximately 1.6 million tonnes of toxic chemicals are released annually into the environment without any treatment, of which $65 \%$ are released directly into the air [7].

US EPA has been trying to reduce the emission of VOCs, such as toluene, xylene, benzene and phenol, which

Received: 11 December 1997

J. Peixoto, M. Mota

Departamento de Engenharia Biológica da Universidade do Minho, Campus de Gualtar, P-4710 Braga, Portugal

Correspondence to: M. Mota are, in general, considered photo-reactive. They are common pollutants of surface and underground water, as well as of gas streams. For US EPA, they are priority environmental pollutants. All are photochemical oxidants and their emission should be limited to a maximum of $160 \mu \mathrm{g} / \mathrm{m}^{3}$, during one hour, never being allowed to exceed this limit more than once a year.

Toluene is widely used as a solvent (paints and coatings, gums, resins, rubber) as well as a reagent (medicines, dyes, perfumes) and is one of the components of gasoline. Its manufacturing sources are the petroleum refining and the coal tar distillation [10].

It is a colourless liquid, with $M=92.141 \mathrm{~g} / \mathrm{mol}$, $S=515 \mathrm{mg} / \mathrm{l}$ in water and $\rho=0.867 \mathrm{~g} / \mathrm{cm}^{3}$, the last two at $20^{\circ} \mathrm{C}$ [6]. In the air, it is detected from concentrations of about $1 \mathrm{mg} / \mathrm{m}^{3}$ by its characteristic odour [10].

\section{2}

\section{Degrading microorganisms}

The properties of the biocatalysts, namely their high affinity for the substrate, make possible their utilization even with very low substrate concentrations. The use of room temperatures, and the harmless products from the pollutants oxidation (e.g., carbon dioxide and water) are the most attractive characteristics of bioprocesses. The main advantage is obvious: the pollutant is not only being transferred from one phase to another. It is effectively eliminated. Besides, the removal bioprocesses are relatively cheap and have good operating stability.

The genus Pseudomonas is widely studied for the degradation of aromatic compounds. These bacteria are known for their ability to grow in various sources of carbon. They are able to degrade aromatic compounds even in the presence of toxic chemicals like potassium cyanide. These properties, along with the production of polysaccharides for the adhesion to surfaces, explain why they are so widely studied for technological applications. They are mesophiles, flagellated, appearing as isolated rods [4]. Average dimensions are $0.75 \times 2.75 \mu \mathrm{m}$. No latent forms are known. For P. fluorescens and P. putida the optimum temperature for growth lies between 25 and $30{ }^{\circ} \mathrm{C}$, although they are able to grow between 4 and $40{ }^{\circ} \mathrm{C}$. The enzymatic content of the bacteria varies, qualitative and quantitatively, according to the surrounding conditions. Temperature, $\mathrm{pH}$, the amount of oxygen and the presence of substrates are important factors that influence the enzymatic content.

The cleavage of the aromatic ring is the fundamental step towards the mineralization of the aromatic com- 
pounds. The ortho-cleavage [9] constitutes the pathway referred to as the $\beta$-ketoadipate pathway. A great variety of aromatic compounds are metabolized using this pathway.

Pseudomonas cells, grown with glucose, are not able to oxidize aromatic compounds at a significant rate, suggesting that the enzymes for the oxidation of those compounds may be inductive. The induction requires the presence of the inductors, and therefore, the bacteria have to be adapted to the degradation of the desired substrates. The adapting process consists, basically, of using a succession of batch cultures, increasing progressively the concentration of the inducing substrate. The absence or the significant reduction of the lag phase is an indicator of the success of the adaptation. The adaptation process may last several weeks.

Usual systems with fixed biomass include the trickling filters and biofilters. The main difference between these two systems lies in the liquid phase. In the trickling filters the liquid phase is constantly being recirculated, whereas in the biofilters the liquid phase is stationary. Supports in each case are also different [13].

It is fundamental to assure a minimum liquid flow to achieve the wetting of the support so that the biomass may have the conditions for survival and growth.

Many kinds of supports may be applied. Raschig rings, due to their simplicity and good behaviour in many applications, are widely used. The support porosity above 0.70 is a very important feature when a biofilm is to be present. The pressure drop is not too high, provided that the biomass leaves enough area for the circulation of both gas and liquid streams. Factors such as a high length to diameter ratio may lead to flooding. Several authors refer experimental problems where clogging proves to be difficult to overcome. Alonso et al. [11] state that a method for the control of biomass accumulation (e.g., backwashing) is essential to sustain high levels of performance. Using an apparatus similar to the one of the present research and $P$. putida, Pedersen et al. [12] called the attention upon the need for investigations of the biofilm growth in the filters, in order to prevent clogging and to optimize and control the purification process.

In the present work the removal of toluene mixed with air by a special mixing device was studied. A trickling filter set-up is the used technology.

\section{2}

\section{Materials and methods}

\section{1}

\section{Chemicals}

Toluene was obtained from Riedel-de Haën, and phenol from Merck. Phenol concentration was assayed by measuring absorbance at $270 \mathrm{~nm}$. Vapours (water, toluene) and gases (oxygen, carbon dioxide, nitrogen) were assayed by MS.

\section{2}

\section{Equipment}

Basically, the installation may be divided into four parts: the column, the fermentor, the mixing chamber [3] (allowing to assay for a range of solvent concentrations varying from 40 to more than $5000 \mathrm{ppm}$, in the case of toluene) and the mass spectrometer (see Fig. 1 for more details).

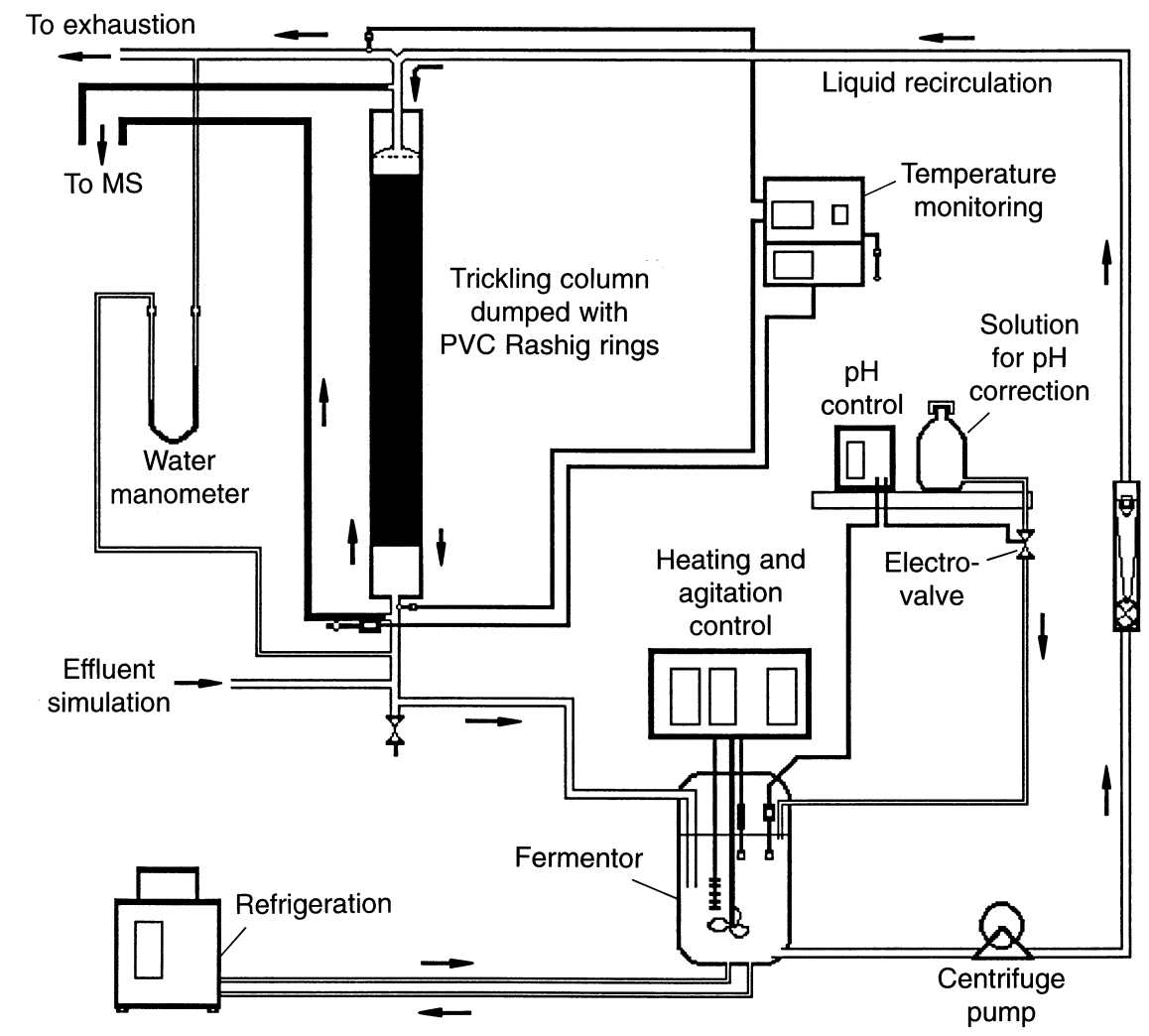

Fig. 1. Schematic representation of the experimental set-up 
The column (packed portion) was a PVC tube, with $10.30 \mathrm{~cm}$ internal diameter and $147.6 \mathrm{~cm}$ high. The packing was composed by dumped PVC Raschig rings, with average dimensions of $1.6 \times 1.6 \times 0.15 \mathrm{~cm}$, having a specific area of $291 \mathrm{~m}^{2} / \mathrm{m}^{3}$. The initial bed porosity, before the bacterial growth, was 0.801 .

The fermentor (Setric Genie Industriel) was a glass cylinder with 6.8 litre capacity. Temperature and $\mathrm{pH}$ controls were available. Heating and refrigeration devices allowed a maximum variation of $0.2{ }^{\circ} \mathrm{C}$.

The connections between the column and the MS (Bioquad $^{\mathrm{TM}}$, Ledamass, England) were performed with $6 \mathrm{~mm}$ diameter stainless steel tubes, coupled to a heating resistance $\left(40<T<50{ }^{\circ} \mathrm{C}\right)$ to avoid the occurrence of moisture in the gas stream. The MS spectra made possible to quantify each flow. The quantification method was based on the sensitivity of toluene (and other gases) related to nitrogen [8].

The air from a compressed air system flowed through one of two rotameters (Fisher \& Porter ${ }^{\mathrm{TM}}$; high flow: FP D10 A1197 A; small flow: FP 10 A6131 NA 2B), covering the operating flow range.

\section{3}

\section{Microorganism adaptation}

The degrading bacteria was Pseudomonas putida ATCC 17484 , available in slants with solid media. This organism uses the $\beta$-ketoadipate pathway for the oxidation of aromatic compounds. The proceedings for the adaptation were basically the inoculation of $500 \mathrm{ml}$ flasks containing $200 \mathrm{ml}$ of mineral media without carbon source (see Table 1). To each flask a blend of an easily oxidizable carbon source -glucose- and an aromatic carbon source -phenolwas added. The initial concentration of glucose was $100 \mathrm{mg} / \mathrm{l}$, whereas phenol concentration was only $50 \mathrm{mg} / \mathrm{l}$. In further assays, the amount of glucose was progressively reduced and, simultaneously, the phenol content was increased. In the final assays phenol was the only carbon source supplied, with a concentration of $600 \mathrm{mg} / \mathrm{l}$. To verify whether there was an influence of micronutrients or glucose on phenol degradation, flasks containing $600 \mathrm{mg} / \mathrm{l}$ of phenol and $50 \mathrm{mg} / \mathrm{l}$ of glucose or $50 \mathrm{mg} / \mathrm{l}$ of yeast extract or $50 \mathrm{mg} / \mathrm{l}$ of both were also put to grow in an orbital shaker set at $150 \mathrm{rpm}$ and $27^{\circ} \mathrm{C}$.

The biomass and the phenol concentration were determined in an UV/Vis spectrophotometer, respectively, at $600 \mathrm{~nm}$ and $270 \mathrm{~nm}$.
After the adaptation period with phenol, the fermentor was inoculated with $P$. putida.

\section{4}

\section{Start-up}

About eight litres of mineral media with glucose $(50 \mathrm{mg} / \mathrm{l})$, yeast extract $(50 \mathrm{mg} / \mathrm{l})$ and phenol $(200 \mathrm{mg} / \mathrm{l})$ were added to the fermentor. The stirring speed was set at $250 \mathrm{rpm}$, the reference $T$ at $27^{\circ} \mathrm{C}$ and the $\mathrm{pH}$ at 6.8. Air and water flows were regulated to $444 \mathrm{l} / \mathrm{h}$ and $307 \mathrm{l} / \mathrm{h}$, respectively.

The flow of toluene was regulated, in the mixing chamber, in order to assure a concentration below $100 \mathrm{ppm}$, for the acclimation of the bacteria to its future unique substrate.

\section{3}

\section{Results and discussion}

\section{1}

\section{Flows, loading zones and flood points}

The minimum wetting rate, calculated according to Coulson and Richardson [1] and Perry and Green [5], was around $135 \mathrm{l} / \mathrm{h}$. The liquid flows, corresponding to the flood points, were determined for each of the gas flows. Experimental liquid flows (see Table 2) were chosen so that they would never exceed $25 \%$ of the flooding liquid flows. Higher flow rates were used to diagnose some diffusion problems [2] but were not plotted in Figs. 3 and 4. Some limitations of the pumping device did not allow to work with flows within the loading zone but the minimum wetting rate was always largely exceeded, thereby meeting the needs of the biological film.

\section{2}

\section{Hold-up and pressure drop}

The expected pressure drop in the flood point would be of about $33 \mathrm{~cm} \mathrm{H} \mathrm{H}_{2} \mathrm{O} / \mathrm{m}$, or $3.3 \mathrm{kPa} / \mathrm{m}$, according to Perry and Green [5]. The measured pressure drops, operating very far from the flood point, were very low, exceeding $4.0 \mathrm{~cm} \mathrm{H}_{2} \mathrm{O}$ only for high gas flows (above $60 \mathrm{l} / \mathrm{min}$ ). These flows are too high to be tested with bacteria because of the little contacting times that would be obtained. Holdup volumes varied between 1.0 and $1.6 \mathrm{l}$ as expected. During the bacterial growth on the column packing, both pressure drop and hold-up increased, never exceeding $20 \%$ of the values without biomass.
Table 1. Mineral media without carbon source for $P$. puti$d a(\mathrm{~g} / \mathrm{l}$ if not mentioned)

\begin{tabular}{|c|c|c|c|c|}
\hline $\begin{array}{l}\mathrm{K}_{2} \mathrm{HPO}_{4} \\
0.5\end{array}$ & $\begin{array}{l}\mathrm{FeSO}_{4} \cdot 7 \mathrm{H}_{2} \mathrm{O} \\
0.01\end{array}$ & \multicolumn{2}{|c|}{$\begin{array}{l}\mathrm{NH}_{4} \mathrm{NO}_{3} \\
3\end{array}$} & Trace solution \\
\hline $\begin{array}{l}\mathrm{MgSO}_{4} \cdot 7 \mathrm{H}_{2} \mathrm{O} \\
0.2\end{array}$ & $\begin{array}{l}\mathrm{CaCl}_{2} \cdot 2 \mathrm{H}_{2} \mathrm{O} \\
0.015\end{array}$ & \multicolumn{2}{|c|}{$\begin{array}{l}\left(\mathrm{NH}_{4}\right)_{2} \mathrm{SO}_{4} \\
2.5\end{array}$} & $1 \mathrm{ml}$ \\
\hline \multicolumn{5}{|l|}{ Trace solution } \\
\hline $\begin{array}{l}\mathrm{CoCl}_{2} \cdot 6 \mathrm{H}_{2} \mathrm{O} \\
0.08\end{array}$ & $\begin{array}{l}\mathrm{KBr} \\
0.21\end{array}$ & $\begin{array}{l}\mathrm{BaCl}_{2} \cdot 2 \mathrm{H}_{2} \mathrm{O} \\
1.30\end{array}$ & $\begin{array}{l}\mathrm{SnCl}_{2} \cdot 2 \mathrm{H}_{2} \mathrm{O} \\
0.79\end{array}$ & $\begin{array}{l}\mathrm{MnSO}_{4} \cdot 5 \mathrm{H}_{2} \mathrm{O} \\
13.42\end{array}$ \\
\hline $\begin{array}{l}\mathrm{MgCl}_{2} \cdot 6 \mathrm{H}_{2} \mathrm{O} \\
0.22\end{array}$ & $\begin{array}{l}\mathrm{LiCl} \\
0.51\end{array}$ & $\begin{array}{l}\mathrm{ZnCl}_{2} \\
0.34\end{array}$ & $\begin{array}{l}\mathrm{CuSO}_{4} \cdot 5 \mathrm{H}_{2} \mathrm{O} \\
0.32\end{array}$ & $\begin{array}{l}\mathrm{H}_{3} \mathrm{BO}_{3} \\
0.26\end{array}$ \\
\hline
\end{tabular}




\section{3}

\section{Porosity and contacting times}

The contacting times between gas and liquid flows were initially based on the packing without the liquid phase and the biomass. Those values had to be corrected along the experiment because of the fixation of the bacteria to the particles, which caused a drop in porosity from 0.801 to 0.324 , without considering the liquid hold-up. The reduction in the available porosity due to liquid hold-up was determined to be $10 \%$ in the final experimental conditions.

\section{4}

\section{Bacterial growth and adhesion}

Grown in a media with glucose and phenol, the bacteria began the degradation of phenol as soon as glucose consumption was achieved. After three consecutive batches, always beginning with a small amount of glucose, the microorganisms could degrade $600 \mathrm{mg} / \mathrm{l}$ of phenol in four days. Flasks containing phenol and $50 \mathrm{mg} / \mathrm{l}$ of glucose and/or $50 \mathrm{mg} / \mathrm{l}$ of yeast extract had a higher phenol oxidation rate, although the difference was not too significant. Therefore, in all the following procedures, including the start-up of the continuous assays, $50 \mathrm{mg} / \mathrm{l}$ of glucose and an equal amount of yeast extract, together with the mineral media and the phenol, were incorporated in the culture medium.

After having adapted the bacteria to phenol degradation, the continuous process was started to evaluate the capacity of the bacteria to degrade toluene. The room temperature was about $29.5^{\circ} \mathrm{C}$ and the inside operating temperature was $27^{\circ} \mathrm{C}$. The initial biomass concentration, in the fermentor, was below $3 \mathrm{mg} / \mathrm{l}$ (absorbance $<0.008)$.

After eleven days of evolution, the biomass in the fermentor reached what would become the highest determined concentration: $1.0 \mathrm{~g} / \mathrm{l}$ (dry weight per litre) (see Fig. 2). During this period, the degradation of phenol proceeded as with the batch runs, but the fixation of the biomass to the particles was not visible yet.

The biomass concentration in the circulating medium decreased steadily because most of the biomass was then being retained in the column packing. After one month of contact the biofilm became easily detected by simple visual inspection. Most of the readings were obtained during the following weeks, with the flows described in Table 2.

\section{5}

\section{Removal of toluene}

Figures 3 and 4 clearly reveal the variation of the removed percentage of toluene either with the increase of the concentration of pollutant or with the reduction of the contacting times. Outlet concentrations below $100 \mathrm{ppm}$, as demanded by legislation, were achieved only for inlet toluene concentrations below $600 \mathrm{ppm}$ or $800 \mathrm{ppm}$, with the lower flows. In Fig. 4, the high values of inlet and outlet concentrations were omitted because they were exceeding largely the allowed $100 \mathrm{ppm}$.

Invariably, the values of removal increased during the assays with the higher liquid flows. As a significant ex-
Table 2. Gas $(G)$ and liquid $(L)$ flows, actual contacting times (with biomass) and inlet concentration of toluene

\begin{tabular}{llll}
\hline $\begin{array}{l}G \\
(1 / \mathrm{min})\end{array}$ & $\begin{array}{l}L \\
(1 / \mathrm{min})\end{array}$ & $\begin{array}{l}t_{C} \\
(\mathrm{~s})\end{array}$ & $\begin{array}{l}\text { Toluene } \\
(\mathrm{ppm})\end{array}$ \\
\hline 2.94 & 4.90 & 81 & $150,450,1530,2750,5330$ \\
& 8.28 & & 150 \\
4.85 & 4.80 & 49 & $160,320,1330,3460$ \\
& 8.07 & & 160,3460 \\
7.20 & 4.60 & 33 & $60,120,710,1970,3390$ \\
& 7.67 & & 60,3390 \\
12.05 & 4.50 & 20 & $40,150,490,1450,1920$ \\
& 7.57 & & 40,1920 \\
\hline
\end{tabular}

Only the points referring to the lower liquid flows were plotted (Figs. 3 and 4)

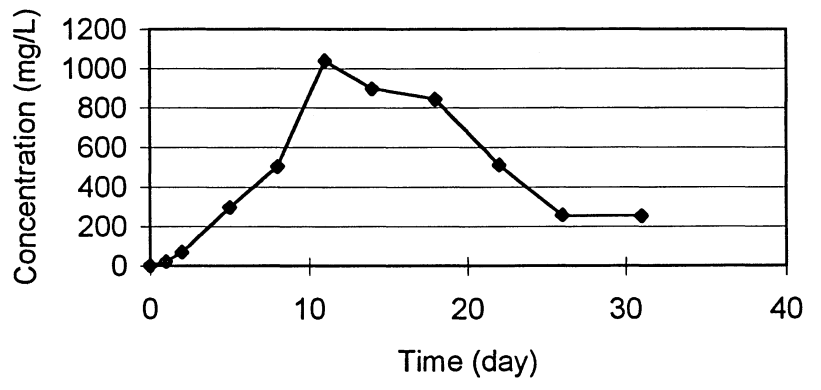

Fig. 2. Evolution of the biomass concentration in the circulating liquid, during the start-up

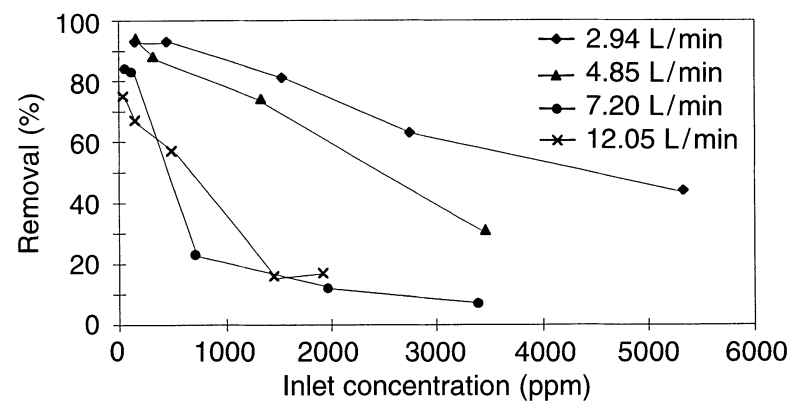

Fig. 3. Removal of toluene as a function of the inlet concentration, for different gas flow rates

ample, for a gas flow of $12.05 \mathrm{l} / \mathrm{min}$, the removal increased from 75 to $80 \%$, with the lowest inlet concentration and from 17 and $28 \%$, with the highest. This fact suggests that some diffusion problems might be occurring, thereby limiting the yield of the process.

During the assays with biomass, no significant or unexpected changes in the hydrodynamic conditions of the column were noticed. However, the build-up of biofilm in the base support of the packing caused clogging and finally obliged the stop of the experimentation.

It must be stressed that a $94 \%$ removal could be obtained for inlet toluene concentrations of less than $400 \mathrm{ppm}$ and for gas flows lower than $2.94 \mathrm{l} / \mathrm{min}$. The outlet toluene concentrations were, in this case, well below the legal 100 ppm limit. 


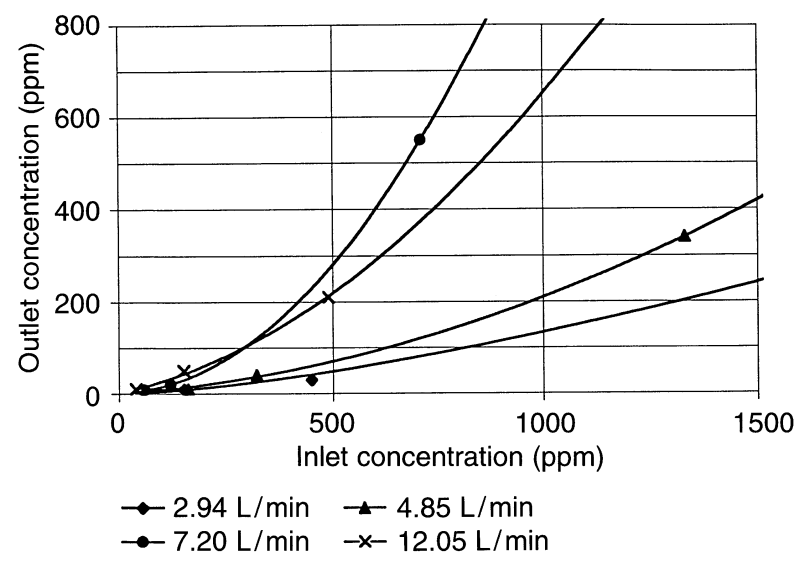

Fig. 4. Relation between the inlet and outlet concentrations of toluene

\section{4}

\section{Conclusions}

The MS proved to be a reliable means for the quantification of the gases and vapours involved.

The mixing chamber allowed to assay for a range of solvent concentrations varying from 40 to more than $5000 \mathrm{ppm}$, in the case of toluene, which demonstrates its large versatility. Pseudomonas putida ATCC 14748 is a microorganism that demonstrated to have good characteristics for adhesion to PVC and for the degradation of phenol and toluene, keeping its activity even in the presence of high concentrations of those compounds.

It was shown that this kind of bioreactor-trickling filter-is able to be used in the removal of toluene for a given set of air flow rates and toluene concentrations. Further experimentation with a system where clogging problems are overcome, may improve its performance and long-term operation.

\section{References}

1. Coulson, J.M.; Richardson, J.F.: Chemical Engineering, Vol. II - Unit Operations. Pergamon Press, 2nd Edn, 1974

2. Fletcher, M: Bacterial Metabolism in Biofilms. In: L.F. Melo et al. (eds) Biofilms-Science and Technology, Kluwer Academic Publishers (1992) 113-124

3. Peixoto, J.; Mota, M: Volatile organic compounds evaporation chamber for the simulation of gas effluents in laboratory research. Biotech. Techniques 11 (1997) 1-6

4. Pelczar, M.J.; Chan, E.C.S.; Krüg, N.R.: Microbiology-Concepts and Applications, McGraw-Hill, 1993

5. Perry, R.H.; Green, D.: Perry's Chemical Engineers' Handbook, 6th Edn. New York, McGraw-Hill International Editions, Chemical Engineering Series, 1984

6. Reid, R.C.; Prausnitz, J.M.; Sherwood, T.K.: The properties of Gases and Liquids, 3rd Edn. New York, McGraw-Hill Chemical Engineering Series, 1977

7. Ritchie, B.J.; Hill, G.A.: Biodegradation of phenol pollutedair, using an external loop airlift bioreactor. J. Chem. Tech. Biotechnol 62 (1995) 339-344

8. Spectra, Bio-Quad Manual

9. Stanier, R.Y.; Ingraham, J.L.; Wheelis, M.L.; Painter, P.R.: General Microbiology, 5th Edn. New Jersey, Prentice-Hall 1986

10. Verschueren, K.: Handbook of Environmental Data on Organic Chemicals, 2nd Edn. New York, van Nostrand Reinhold, 1983

11. Alonso, C.; Suidan, M.T.; Sorial, G.A.; Smith, F.L.; Biswas, P.; Smith, P.J.; Brenner, R.C.: Gas treatment in trickle-bed biofilters: biomass, how much is enough. Biotech. and Bioeng. 54 (1997) 583-594

12. Pedersen, A.R.; Møller, S.; Molin, S.; Arvin, E.: Activity of toluene-dedrading Pseudomonas putida in the early growth phase of a biofilm for waste gas treatment. Biotech. and Bioeng. 54 (1997) 131-141

13. Ottengraf, S.P.P.: Biological systems for waste gas elimination. Trends Biotech. 5 (1987) 132-136 